\title{
Pengaruh Umur Beranak Pertama Terhadap Performa Produksi Susu Sapi Friesian Holstein di BBPTU-HPT Baturraden
}

\author{
Effect of first calving Friesian Holstein age on milk yield performance at BBPTU-HPT Baturraden \\ J. S. Awan ${ }^{1}$, A. Atabany ${ }^{2}$ \& B. P. Purwanto ${ }^{3}$ \\ ${ }^{1)}$ Mahasiswa Program Studi Ilmu Produksi dan Teknologi Peternakan, Sekolah Pascasajana, Institut Pertanian \\ Bogor \\ ${ }^{2)}$ Departemen Ilmu Produksi dan Teknologi Peternakan, Fakultas Peternakan \\ ${ }^{3)}$ Program Diploma, Institut Pertanian Bogor. \\ Jln. Agatis, Kampus IPB Dramaga Bogor 16680, Indonesia. \\ Correspondence author: johansetiawan1000@yahoo.co.id
}

\begin{abstract}
The objective of this study was to observe effect of first cavling Friesian Holstein age on milk yield performance at BBPTU-HPT Baturraden. This study was conducted using 150 sets of weekly recording of milk yield from 350 Friesian Holstein cows. Milk yield was calculated by using time interval method (TIM) which was equvalent to ME 305 days. The data were analysed using polynomial regression model. Result of the study indicated that BBPTU-HPT has made efforts to improve the age first calving, but has an impact on longer day open and shorter period of lactation with longer dry period so that calving interval has been longer than what's been indicated not efficient and optimal. The age first calving significant through milk yield followed the pattern of linear regression.
\end{abstract}

Keywords: frisian holstein cows, calving age, reproduction performance, milk yield, regression models.

\section{PENDAHULUAN}

Sapi perah yang banyak dipelihara oleh masyarakat Indonesia adalah sapi Friesian Holstein yang memiliki produk utama susu. Susu merupakan, bahan makanan yang menjadi sumber gizi dengan nilai yang sangat baik. Kebutuhan susu dari tahun ke tahun terus meningkat, seiring dengan bertambah jumlah penduduk dan tingkat kesadaran kebutuhan gizi masyarakat yang didukung oleh ilmu pengetahuan dan teknologi. Laju pertumbuhan populasi sapi perah setiap tahun meningkat tetapi sapi perah yang memproduksi susu belum mampu memenuhi kebutuhan konsumsi susu dalam negeri, sehingga dilakukan impor susu dan produk olahan susu untuk memenuhi kebutuhan.

Produksi susu nasional tahun 2015 mencapai 805 juta ton, dengan populasi sapi perah 525.000 ekor (Dikjetnak 2015). Peningkatan produksi susu dan populasi sapi perah dapat dilakukan melalui membuat sentra peternakan sapi perah peranan pemerintah dan memperbanyak sekolah pertanian di berbagai provinsi dan melakukan evaluasi parameter produksi susu dan reproduksi sapi perah yang dilakukan terus-menerus, sehingga mendapatkan performa produksi susu dan reproduksi sapi perah yang efisien.

Kejadian umur beranak pertama sapi $\mathrm{FH}$ di Indonesia sangat beragam. Beragamnya umur beranak pertama ini, akan menyebabkan beragamnya total produksi susu per laktasi yang dihasilkan. Laporan hasil penelitian terdahulu menurut Wicaksono et al. (2004) bahwa rata-rata umur beranak pertama di Cicurug, Sukabumi 32,9 bulan.
Menurut Makin (2001) rata-rata umur beranak pertama sapi FH di Jawa Barat 28,88 bulan Sariwiyono et al. (1993) menyatakan rata-rata umur beranak pertama sapi $\mathrm{FH}$ di Pujon, Kota Batu dan Karang Ploso Malang Jawa Timur adalah 28,2; 32,8 dan 30,8bulan. Peningkatan produksi susu pada dasarnya dapat dilakukan melalui perbaikan mutu genetik dan manipulasi lingkungan, serta perbaikan manajemen pemeliharaan.

Salah satu perbaikan manajemen yang dapat dilakukan, yaitu perbaikan umur beranak pertama pada peternakan sapi perah. Penelitian yang telah dilakukan di Indonesia untuk melihat keterkaitan antara umur beranak pertama dengan produksi susu masih jarang dilakukan. Penelitian ini dilakukan untuk menganalisis pengaruh umur beranak pertama terhadap performa produksi susu untuk menerapkan manajemen yang efisien dan optimal dalam pemeliharan sapi FH. Hasil penelitian ini diharapkan dapat memberikan informasi dasar bagi pengembangan peternakan sapi perah rakyat di Indonesia, mengenai pentingnya menetapkan umur beranak pertama dalam kaitannya dengan performa produksi susu yang optimal dalam rangka peningkatan efisien pemeliharan.

\section{MATERI DAN METODE}

Tempat dan Waktu Penelitian

Penelitian dilakukan di Balai Besar Pembibitan Ternak Unggul dan Hijauan Pakan Ternak (BBPTU-HPT) Sapi Perah Baturraden, Kecamatan Baturraden, Kabupaten 
Purwokerto, Provinsi Jawa Tengah. Lokasi penelitian ini mempunyai suhu udara minimum $18{ }^{\circ} \mathrm{C}$ dan suhu maksimum $28{ }^{\circ} \mathrm{C}$, dengan kelembaban udara $70 \%-80 \%$ serta curah hujan per tahun $6.000-9.000 \mathrm{~mm}$. Penelitian dilakukan pada bulan Agustus sampai dengan bulan Nopember 2016.

\section{Bahan dan Prosedur Penelitian}

Bahan yang digunakan dalam penelitian ini adalah data reproduksi dan produksi susu sapi FH di BBPTU-HPT Baturraden. Data sekunder yang dikumpulkan meliputi catatan produksi susu mingguan (dua kali pemerahan pada pukul 02.00 dan 14.00 WIB setiap hari), tanggal lahir, tanggal beranak, tanggal inseminasi dan tanggal kering kandang dari setiap ekor induk sapi. Data sekunder tersebut berasal dari induk sapi yang beranak pertama pada tahun 1986 sampai dengan 2015. Data sapi FH yang digunakan dalam penelitian ini, berasal dari 852 ekor. Parameter yang diukur diantaranya, umur beranak pertama, masa kosong, masa laktasi, total produksi susu dan produksi susu harian, masa kering. Produksi susu catatan mingguan yang telah diestimasi mengunakan Test Interval Method (TIM). Hasil produksi susu dari (TIM) dan dilakukan 305 hari SD (setara dewasa), untuk mengurangi keragaman produksi susu, karena faktor umur dari masa laktasi (dalam satuan $\mathrm{kg}$ ). Diurutkan kejadian umur-umur beranak pertama sapi FH dari yang muda sampai yang tua terhadap produksi susu 305 hari SD. Semua data diianalisis dengan metode deskriptif dan semua penghitungan menggunakan software Microsoft Excel.

\section{Peubah yang Diamati}

Peubah yang diamati meliputi parameter reproduksi dan produksi susu. Parameter reproduksi yaitu umur beranak pertama dan masa kosong. Parameter produksi susu adalah masa laktasi, total produksi susu, produksi susu harian dan masa kering. Umur beranak pertama merupakan umur induk sapi saat beranak yang diperoleh dari beranak pertama. Umur beranak pertama diperoleh dengan cara menghitung jumlah hari antara tanggal lahir induk sapi hingga tanggal beranak pertama. Masa kosong adalah rentang waktu (dihitung dalam hari) dari induk sapi beranak sampai sapi tersebut, dikawinkan (IB) kembali yang menghasilkan kebuntingan.

Masa laktasi adalah periode atau lamanya sapi diperah (dihitung dalam hari) untuk memproduksi susu yaitu dari awal sapi beranak hingga sapi dikering kandangkan. Produksi susu diperoleh dari catatan mingguan yang telah diestimasi mengunakan Test Interval Method (TIM) dan kemudian produksi susu 305 hari SD untuk mengurangi keragaman produksi susu karena faktor umur dari masa laktasi dalam satuan kg. Masa kering adalah sapi induk FH yang dikeringkan atau diberhentikan pemerahannya 50 atau 60 hari sebelum perkiraan tanggal kelahiran pedet. Masa kering diperoleh dengan cara menghitung jarak sapi dikering kandangkan sampai sapi tersebut beranak atau melahirkan pedet

\section{Analisa Data}

Data produksi susu yang diperoleh, kemudian diestimasi mengunakankan Test Interval Method (TIM) menurut model estimasi yang digunakan pada penelitian Norman et al. (1999) yang ditentukan sebagai berikut :

$$
\mathrm{Ye}=\mathrm{d} / 2(\mathrm{y} 1+\mathrm{y} 2)
$$

Keterangan:

Ye $=$ produksi susu estimasi

$\mathrm{d}=$ selang hari pemerahan y1 dengan y2

$\mathrm{y} 1=$ produksi susu pemerahan pertama

y2 = produksi susu pemerahan ke dua

Hasil dari estimasi produksi susu mengunakan (TIM), kemudian dilakukan faktor koreksi susu 305 hari SD, menurut Hardjosubroto (1994) adalah dengan cara (1) menggunakan faktor koreksi 1.0 untuk panjang laktasi 305308 hari; (2) mengunakan faktor koreksi di atas 1.0 apabila panjang laktasi kurang dari 305; dan (3) menggunakan faktor koreksi di bawah 1.0 apabila panjang laktasi lebih dari 308 hari. Misalnya sebagai contoh adalah apabila panjang laktasi 270, 280, 290, dan 300 hari, maka faktor koreksinya secara berurutan adalah 1,$08 ; 1,06 ; 1,03$; dan 1,01. Faktor koreksi apabila panjang laktasi 309-312 adalah 0,99.

Hasil produksi susu yang di estimasi 305 hari SD, kemudian diurutkan berdasarkan umur beranak pertama yang termuda sampai dengan yang tua terhadap produksi susu 305 hari SD, dan untuk melihat hubungan anatara produksi susu 305 hari SD dengan umur beranak pertama, maka dilakukan analisis dengan regresi nonparametrik dimana fungsi regresi (X) (predictor) atau umur beranak pertama ditaksir menggunakan bentuk polinomial. Pada regresi polinomial persamaan regresi di Fit terhadap (X) (precdictor) atau umur beranak pertama dengan tiga taraf yaitu persamaan regresi linier $(\mathrm{X})$, kuadratik $\left(\mathrm{X}^{2}\right)$ dan kubik $\left(\mathrm{X}^{3}\right)$ dengan bantuan perangkat lunak MINITAB 16. Analisis regresi polinomial dengan model matematika mengacu pada Steel dan Torrie (1997) yang tertulis sebagai berikut:

$$
\begin{array}{lll}
\text { Linier } & : & Y=Y_{1}+b_{0}+b_{1} X+e_{1} \\
\text { Kuadratik } & : & Y=Y_{1}+b_{0}+b_{1} X+b_{2} X^{2}+e_{1} \\
\text { Kubik } & : & Y=Y_{1}+b_{0}+b_{1} X+b_{2} X^{2}+b_{3} X^{3}+e_{1}
\end{array}
$$

Keterangan:

$$
\begin{array}{ll}
\mathrm{Y} & : \text { produksi susu } \\
\mathrm{X} & : \text { umur beranak pertama } \\
\mathrm{b}_{0} & : \text { intercep } \\
\mathrm{b}_{1}, \mathrm{~b}_{2}, \mathrm{~b}_{3} & : \text { koefisien regresi parsial } \\
\mathrm{e}_{1} & \text { : galat }
\end{array}
$$

Model terbaik yang memiliki $\mathrm{R}^{2}$ paling tinggi yang dipilih dari ketiga model regresi tersebut. Apabila terdapat dua atau lebih, model memiliki $\mathrm{R}^{2}$ yang sama, maka dipilih model yang lebih sederhana.

\section{HASIL DAN PEMBAHASAAN}

\section{Performa Produksi susu}

Performa produksi susu dan reproduksi sapi $\mathrm{FH}$ adalah suatu ukuran yang sangat perlu diperhatikan dalam manajemen pemeliharaan untuk mencapai efisien dalam peternakan sapi perah. Hasil analisis rata-rata umur beranak pertama adalah 28,10 bulan. Hal tersebut menunjukan bahwa umur beranak pertama sapi FH di BBPTU-HPT Baturraden lebih muda (Tabel 1) dibandingkan di BPPT-SP Cikole dengan rata-rata umur beranak pertama 32,6 bulan (Anggraeni et al. 2008). Kondisi ini menunjukan bahwa 
Tabel 1 Performa reproduksi dan produksi susu sapi FH di BBPTU-HPT Baturraden

\begin{tabular}{lcc}
\hline Parameter & $\mathrm{n}$ & Rataan $\pm \mathrm{SD}$ \\
\hline Umur beranak pertama (bulan/ekor) & 852 & $28,10 \pm 4,05$ \\
Masa kosong (hari/ekor) & 704 & $196,02 \pm 111,40$ \\
Masa laktasi (hari/ekor) & 852 & $300,55 \pm 71,40$ \\
Masa kering (hari/ekor) & 589 & $130,80 \pm 105,26$ \\
Produksi susu (kg/ekor/laktasi) & 852 & $4,135 \pm 1,386$ \\
Produksi susu harian (kg/ekor) & 852 & $14,08 \pm 4,57$ \\
\hline
\end{tabular}

Keterangan: $\mathrm{n}=$ jumlah ternak

sapi FH beranak pertama lebih muda, karena secara tidak langsung dipengaruhi oleh umur, bobot badan, ras, genetik, lingkungkan dan nutrisi pakan. BBPTU-HPT Baturraden melakukan perbaikan manajemen pemeliharaan dari tahun ke tahun, sehingga laju pertumbuhan pedet sampai dara akan tecapai dengan baik dan mempunyai upaya dengan target sapi betina FH dapat beranak pertama 24 bulan dan sapi perah mengalami beranak setahun sekali. Menurut Moran. (2012) sapi dara FH siap dikawinkan pertama kali pada umur 15 bulan dengan bobot badan sekitar 300-350 kg. Menurut Anggraeni et al. (2008) umur kawin pertama sapi FH di BPPT-SP terlambat atau tertunda, karena sapi dara FH dikawinkan mengikuti patokan Japan International Cooperation Agency (JICA), yakni saat dicapai bobot badan sapi dara antara 300-350 kg. Menurut Yamada (1992) standar umur kawin pertama sapi FH dara di Jepang dengan kisaran bobot badan sapi dara antara 350-400 kg, dicapai sekitar umur 15 bulan dan akan beranak pertama 24 bulan. Sapi perah mengalami penundaan umur kawin pertama disebabkan oleh faktor bobot tubuh yang diinginkan belum tercapai pada saat umur kawin pertama dan suhu dan kelembaban yang tinggi merupakan salah satu faktor yang dapat mempengaruhi umur kawin pertama menjadi lebih tua (Atabany 2012).

Masa kosong adalah interval hari mulai dari beranak sampai dengan dilakukan inseminasi atau dikawinkan kembali sampai bunting, (konsepsi). Toelihere (1985) menyatakan sapi setelah beranak menghasilkan susu dan mempersiapkan kembali uterus, ovarium dan organ kelamin lainnya dan sistem endokrin untuk memulai siklus berahi kembali dan reproduksi normal untuk memulai kebuntingan selanjutnya. Hasil penelitian masa kosong 196,02 hari atau 6,53 bulan (Tabel 1). Rata-rata masa kosong sapi FH di BBPTU-HPT Baturraden tergolong panjang, akan terjadi 4-5 kali siklus berahi. Sesuai dengan pendapat Pennington (2007) bahwa siklus berahi pada sapi perah yang normal 18-24 hari dengan rata-rata 21 hari. Bahwa masa kosong yang panjang, karena adanya kesulitan dalam mengawinkan sapi FH kembali setelah beranak. BBPTU-HPT Baturraden, umumnya melakukan palpasi kebuntingan (PKB) yang dilakukan dua bulan setelah IB, untuk memastikan kebuntingan. Sapi perah tidak mengalami kebuntingan, akan menyebabkan umur beranak pertama lebih panjang atau lambat. Sesuai dengan pendapat Atabany (2012) sapi betina FH yang telah dilakukan inseminasi buatan (IB) tidak harus dilakukan palpasi kebuntingan (PKB), karena akan menunda waktu umur beranak, sehingga akan mengalami masa kosong yang panjang dan untuk mengatasi kegagalan pengamatan berahi sapi $\mathrm{FH}$ diperlukan rekording yang baik, pengamatan lebih teliti dan perbaikan manajemen perkawinan.

Masa laktasi adalah masa atau lama waktu yang terjadi saat induk sapi perah memproduksi air susu dimulai setelah beranak sampai dengan sapi perah tersebut dihentikan pemerahannya (masa kering). Hasil analisis masa laktasi 300,55 hari atau 10,02 bulan. Hal tersebut, menunjukan masa laktasi mengalami sedikit lebih pendek dari yang di sarankan yaitu 305 hari masa laktasi normal (Blakely dan Bade 1991). Sapi FH di BBPTU-HPT Baturraden mempunyai masa laktasi yang kurang dari 305 hari, sehingga kemampuan memproduksi susu lebih rendah dari pada sapi $\mathrm{FH}$ daerah asalnya, karena masa laktasi semakin singkat akan menyebabkan penurunan total produksi susu per laktasi, apabila tidak terjadi peningkatan produksi susu harian (Atabany 2012). West et al. (1991) menyatakan suhu lingkungan dan kelembaban yang tinggi dapat menyebabkan sapi laktasi menurunkan performa dan menyesuaikan kondisi fisiologinya.

Masa kering adalah periode atau lamanya sapi berhenti diperah hingga sapi akan menunjukan beranak kembali. Hasil analisis masa kering adalah 130,80 hari atau 4,36 bulan. Masa kering mengalami lebih panjang dari yang disarankan Ball dan Peters (2007) adalah 60 hari yang berguna untuk regenerasi ambing dan persiapan laktasi berikutnya. Masa kering sapi FH di BBPTU HPT Baturraden lebih panjang, yaitu diatas 60 hari, karena masa kosong yang panjang dan melebihi 90 hari dapat dilihat pada (Tabel 1). Hal tersebut, dapat disebabkan oleh manajemen perkawinan yang kurang baik setelah sapi tersebut beranak. Sapi FH laktasi di BBPTU-HPT Baturraden diduga dikeringkan karena tiga hal yaitu produksi susu harian yang telah sedikit tapi tidak bunting, mengalami kebuntingan 7 bulan, dan produksi susu sangat sedikit dan sedang bunting. Sapi laktasi sebaiknya dikeringkan karena produksi susu sedikit dan sedang bunting 7 bulan sebelum beranak untuk memulihkan kondisi tubuh setelah produksi susu. Sesuai dengan pendapat Blakely dan Bade (1991) sapi betina yang dikeringkan atau diberhentikan pemerahannya 50 atau 60 hari sebelum perkiraan tanggal kelahiran pedet, berguna untuk memberikan kesempatan sistem kelenjar ambing serta tubuh sapi itu sendiri pulih dari cekaman stress yang timbul selama masa laktasi.

Produksi susu per laktasi adalah total produksi susu sapi FH selama masa laktasi sampai mengalami produksi susu sangat sedikit atau masa kering dan apabila dibagi dengan jumlah masa laktasinya akan mendapatkan produksi susu harian. Hasil analisis menunjukan produksi susu per laktasi $4.135 \mathrm{~kg} /$ ekor dengan produksi susu harian adalah 14,08 kg/ekor. Sapi FH di BBPTU-HPT Baturraden mempunyai produksi susu lebih tinggi, dibandingkan sapi FH di BPPT-SP Cikole $4.083 \mathrm{~kg} /$ ekor/laktasi dengan produksi susu harian adalah 11,9 kg/ekor pada umur beranak pertama (Anggraeni et al. 2008). Sapi FH di BBPTU-HPT Baturraden mempunyai produksi susu lebih tinggi, karena mempunyai rataan umur beranak pertama lebih muda yaitu 
28,10 bulan (Tabel 1), dibandingkan sapi FH di BPPTSP Cikole adalah 32,6 bulan . Rataan selang beranak satu tahun atau 12-13 bulan, maka keterlambatan umur beranak pertama menyebabkan berkurangnya produksi susu yang dihasilkan sapi FH di BBPT-SP Cikole (Anggraeni et al. 2008). Sapi FH di BBPTU-HPT Baturaden mempunyai produksi susu lebih rendah dibandingkan sapi FH didaerah asalnya, di didaerah beriklim sedang (temperate). Sesuai dengan pendapat Blakely dan Bade (1991) rata-rata produksi susu sapi FH di daerah beriklim sedang adalah 5.750-6.250 $\mathrm{kg}$. Hal tersebut diduga sapi FH yang berada di iklim sedang dipengaruhi oleh tropical degeneration, komsumsi pakan produktif dan genetik yang baik.

\section{Beranak Pertama dan Produksi susu 305 hari SD}

Rata-rata masa laktasi sapi perah di BBPTU-HPT Baturraden adalah 300,55 $\pm 71,40$ hari dengan rata-rata umur beranak pertama $28,10 \pm 4,05$ bulan (Tabel 1). Hasil rata-rata produksi susu 305 hari SD dengan umur beranak pertama kurang dari 21 bulan dan 22-23 bulan dengan produksi susu secara berurutan adalah 4.106,8 kg dan $4.622 \mathrm{~kg}$. Hasil analisis menunjukan bahwa umur beranak pertama yang kurang dari 21 bulan dan 22-23 bulan atau kuarang 24 bulan memiliki rata-rata produksi susu lebih rendah, dibandingkan umur beranak pertama 24-26 bulan (Gambar 1). Inseminasi buatan (IB) dilakukan umur sapi 12-13 bulan, dan sapi FH tersebut bunting, akan mengalami umur beranak pertama 21 bulan dan 22 bulan adalah tergolong umur beranak pertama yang masih muda. Kondisi dapat terjadi karena sapi ratarata pubertas pertama adalah 8-9 bulan didaerah tropis dan 5-6 bulan di daerah sub tropis (Temperate) (Salisbury dan Demarck 1961).

Umur beranak pertama sapi FH yang tergolong muda mempunyai produksi susu yang lebih rendah, karena pakan yang dikonsumsi terbagi untuk memenuhi kebutuhan pokok hidup produksi susu dan untuk memenuhi kebutuhan pokok hidup pada masa pertumbuhan, sehingga menghasilkan produksi susu yang belum maksimal. Menurut Foldager et al. (1988) sapi dara FH mengalami pubertas pertama umur 5-6 bulan dan paling lambat umur $18-20$ bulan dengan bobot badan $150-400 \mathrm{~kg}$. Selanjutnya Salisbury dan Demarck (1961) mengatakan kurang efisien sapi dara beranak pertama pada umur lebih muda, karena kurang mampu menunjukan produksi susu maksimum, maka harus ditunda, perkawianan sapi betina dara sampai mencapai ukuran dewasa yang cukup dan lebih ekonomis

Hasil rata-rata umur beranak pertama 24-26 bulan mempunyai produksi susu 305 hari SD 4.890,3 kg lebih tinggi dibandingkan umur beranak petama 33-35 bulan dan 36-38 bulan, dapat dilihat pada (Gambar 1). Kondisi ini menunjukan, bahwa sapi FH beranak pertama 24-26 bulan adalah umur beranak pertama yang ideal, memiliki sistem reproduksi yang matang atau optimal pada umur 15 bulan yang ideal untuk dilakukan perkawinan atau IB. Hal tersebut bisa terjadi, karena pemberian pakan yang produktif dan konsumsi pakan yang terpenuhi mulai dari pedet sampai sapi dara. Selanjutnya sesuai dengan Moran (2012) umur kawin pertama sapi dara, sebaiknya dilakukan setelah sapi dara tersebut telah mencapai bobot dewasa tubuh, yaitu berumur 15 bulan dengan bobot badan 300$350 \mathrm{~kg}$ dan akan mengalami beranak pertama pada umur 24 bulan. Cozler et al. (2008) menyatakan sapi dara FH mengalami umur pubertas pertama, maka sebaiknya inseminasi buatan atau dikawinkan pertama kali umur 1518 bulan, sehingga menguntungkan suatau peternakan dengan memiliki produksi susu yang maksimum dan selang beranak yang optimal. Menurut Salisbury dan Demarck. (1961) umur kawin pertama sapi FH, apabila mencapai ukuran dewasa tubuh yang cukup, sehingga mengalami banyak keturunan atau masa hidup untuk produksi susu lebih banyak dan ekonomis. Hoffman (1997) menyatakan umur beranak pertama merupakan faktor yang penting untuk mengurangi biaya pemeliharaan sapi dara, sehingga dengan tidak menunda umur kawin dan umur beranak pertama yang optimal, karena dapat meningkatkan efisien biaya pemeliharaan.

Hasil rata-rata umur beranak pertama 33-35 bulan dan 36-38 bulan atau tiga tahun adalah tergolong beranak pertama tua yang memiliki rata-rata produksi susu 305 hari SD $3.632 \mathrm{~kg}$ dan $3.580 \mathrm{~kg}$ adalah tergolong lebih rendah dibandingkan umur beranak pertama 24-26 bulan (Gambar 1). Hal tersebut menunjukan bahwa sapi $\mathrm{FH}$ beranak pertama pada umur 33-35 bulan dan 36-38 bulan, mengalami pertumbuhan terhambat, karena pemberian pakan yang kurang atau nutrisi pakan yang rendah. Sapi betina FH

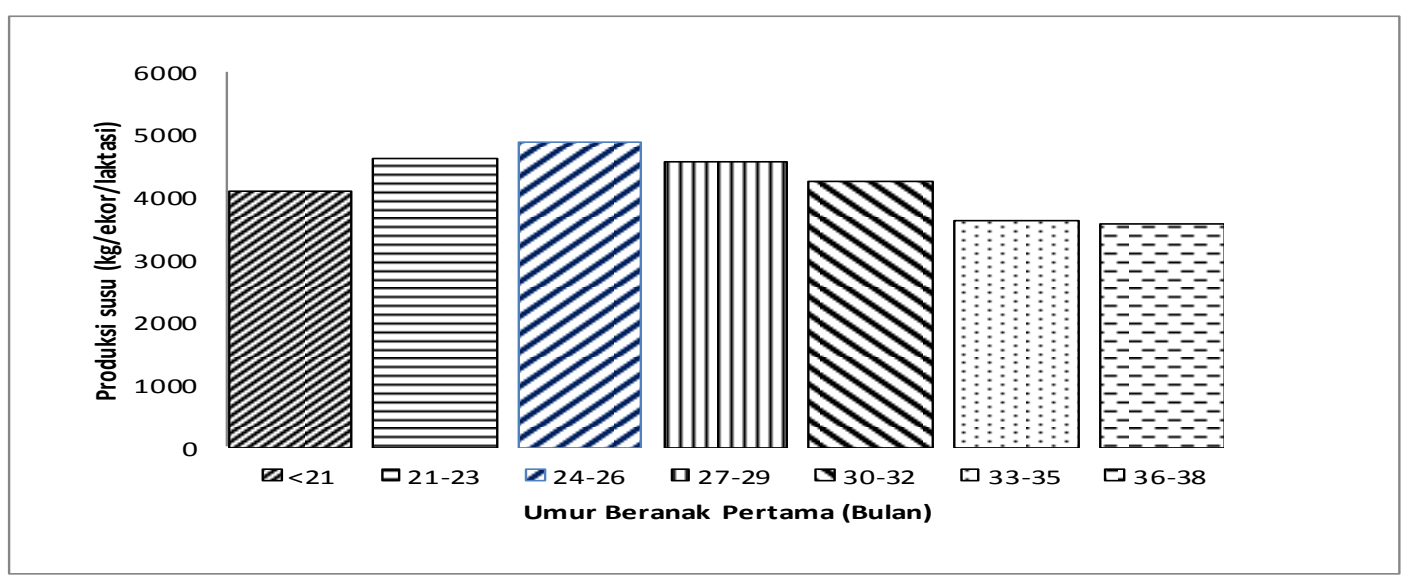

Gambar 1 Hubungan antara umur beranak pertama dengan rataan produksi susu pada 305 hari SD 
mengalami beranak pertama lebih tua, disebabkan karena mengalami bobot badan untuk dikawinkan belum terpenuhi. Menurut Akoso (1996) pakan yang kurang produktif atau nutrisi pakan yang rendah yang diberikan pada sapi $\mathrm{FH}$ akan mengalami berahi yang sangat ringan, tanda-tandanya tidak tampak nyata dan keadaan ini disebut dengan berahi tenang yang menyebabkan berahi yang tidak terdeteksi, sehingga perkawinan tidak dilakukan dan akan menunda beranak pertama sapi FH tersebut dan tidak ekonomis atau tidak efisien. Selanjutnya Abeni et al. (2000); Zanton dan Heinrichs (2005) menunjukkan bahwa sapi perah yang mengalami pertumbuhan terhambat (dengan pertambahan bobot badan kurang dari $0,6 \mathrm{~kg} / \mathrm{hari}$ ) pada masa sebelum dan sesudah puber sampai kawin pertama, akan menghasilkan produksi susu yang lebih sedikit atau rendah.

Hasil analisis menunjukan bahwa pada sapi perah mengalami umur beranak pertama 33-35 bulan (tua), mengalami mundurnya 9 bulan awal produksi susu dan beranak pertama 36-38 bulan adalah hilangnya satu periode laktasi yaitu 305 hari (10 bulan) dan puncak produksi susu, Sapi perah yang beranak pertama tergolong tua memiliki produksi susu yang rendah atau kurang maksimal dan reproduksi pada sapi tersebut tidak efisien. Blakely dan Bade (1991) menyatakan sapi FH mengalami efisien produksi susu atau optimal, apabila memiliki masa laktasi yang normal adalah 305 hari dan masa kering 60 hari dalam setahun. Selanjutnya Cozler et al. (2008) menyatakan sapi perah yang dikawinkan umur yang lebih tua memiliki parameter reproduksi yang tidak efisien dan produksi susu yang tidak optimal, maka kehilangan produktifitas sapi perah selama pemeliharaan. Makin (2011) menyatakan peternakan umumnya sebagian besar mengawinkan sapi dara pada umur 26-28 bulan, sehingga baru beranak pertama pada umur 36 bulan atau 3 tahun dan mengeluarkan biaya lebih banyak sebelum memproduksi susu, sehingga tidak efisien dalam pemeliharaan sapi perah tersebut.

\section{Pengaruh Beranak Pertama dan Produksi Susu 305} hari SD dan kubik yang digunakan untuk memeriksa hubungan antara umur beranak pertama dengan produksi susu SD 305 hari Pengamatan menunjukan persamaan regresi pada tiga taraf semuanya memiliki pengaruh, diantaranya persamaan linier memiliki pengaruh sangat nyata $(\mathrm{P}<0,01)$ terhadap produksi susu SD 305 hari, sedangkan persamaan kuadratik dan kubik adalah memberikan pengaruh nyata $(\mathrm{P}<0,05)$ terhadap produksi susu SD 305 hari. Semua persamaan regresi dengan nilai $\mathrm{R}^{2}$ masing-masing adalah 5,4\%; 6,5\% dan $7,6 \%$. Persamaan sangat nyata berpengaruh terhadap produksi susu adalah persamaan linier, $\mathrm{Y}=7.018-89.06 \mathrm{X}$ dan $\mathrm{R}^{2}=5,4 \%$. Nilai 5,4\% adalah sangat kecil, tetapi sangat nyata pengaruh terhadap produksi susu. Bahwa pengaruh umur beranak pertama sangat kecil untuk keragaman yang dihasilkan pada produksi susu dan terdapat faktorfaktor lain 94,6\% diluar umur beranak pertama yang dapat menyebabakan keragamaan produksi susu. Umur beranak pertama dan masa laktasi yang terlalu beragam, sehingga hubungan dengan produksi susu tidak terlihat jelas. Persamaan linier berpola negatif. Dugaan rata-rata total produksi susu akan berkurang $89,06 \mathrm{~kg}$, ketika umur beranak pertama meningkat 1 bulan dengan asumsi peubah bebas lainnya tetap. Bertambahnya umur beranak pertama dan jarak beranak pertama pada umur 19-36 bulan memiliki efek negatif terhadap produksi susu, dapat dilihat pada (Gambar 2). Menurut Do et al. (2013) mengurangi umur beranak peratama dan jarak beranak pada sapi FH memiliki efek positif dan umur beranak pertama berkurang menjadi 22,3 bulan dari 32,8 bulan, dapat mempengaruhi berbagai faktor ekonomi, akibatnya mempengaruhi kehidupan produktif dan profitabilitas sapi perah.

\section{KESIMPULAN}

\section{Simpulan}

BBPTU-HPT telah melakukan upaya perbaikan umur beranak pertama, tetapi berdampak terhadap masa kosong yang lebih lama dan masa laktasi yang lebih singkat dengan masa kering yang lama sehingga selang beranak

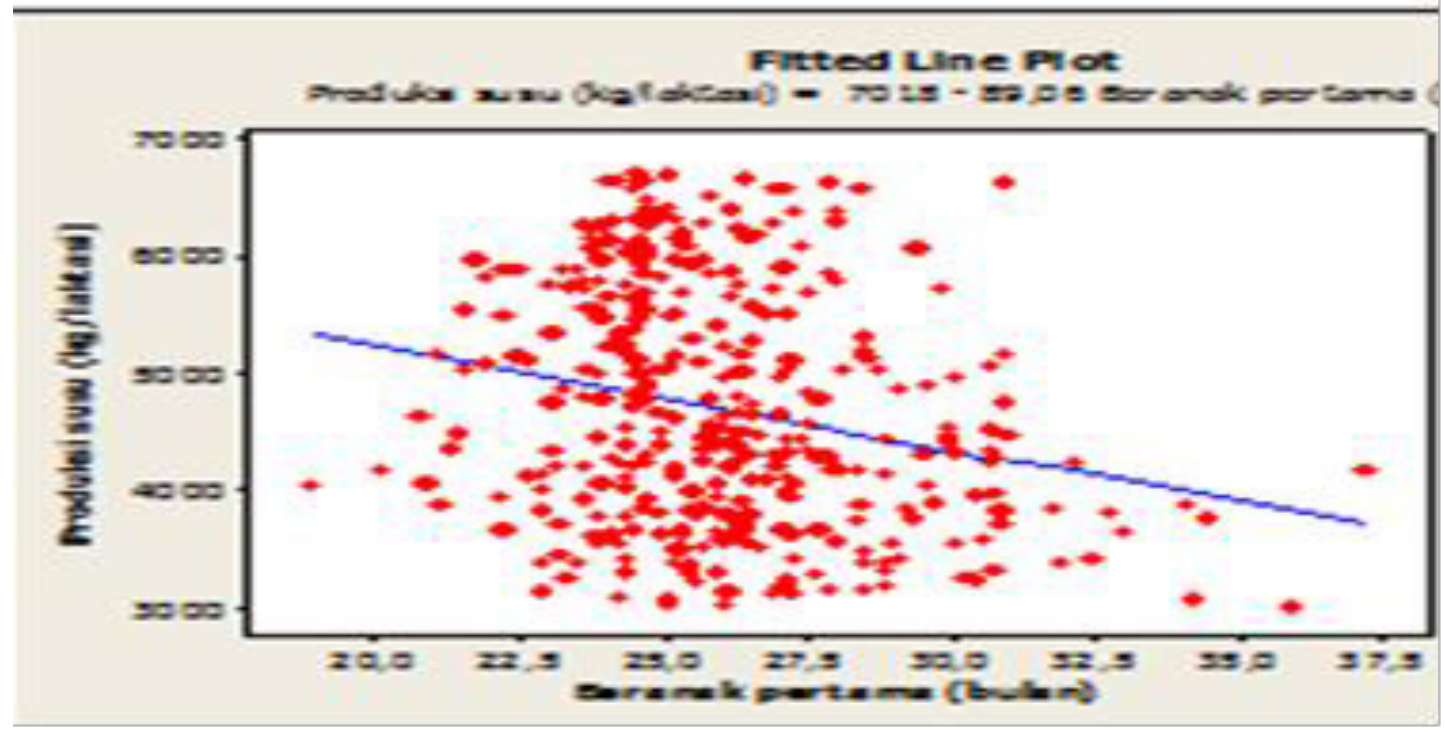

Gambar 2. Plot hubungan umur beranak pertama dengan produksi susu 305 hari SD 
betambah lama yang terindikasi belum efisien dan optimal. Umur beranak pertama sangat nyata berpengaruh terhadap produksi susu mengikuti pola regresi linier.

\section{Saran}

Penilitian umur beranak pertama terhadap produksi susu diberbagai tempat perlu dilakukan untuk dapat dikalborasi sebagai sumber data untuk informasi performa reproduksi dan produksi susu yang optimal sebagai pengembangan sapi perah rakyat dalam rangka peningkatan efisien pemeliharaan di Indonesia.

\section{DAFTAR PUSTAKA}

Akoso BT. 1996. Kesehatan Sapi. Yogyakarta (ID): Kanisius Press.

Abeni F, Calamari L, Steanini L, Pirlo G. 2000. Effects of daily gain in pre-and postpubertal replacement dairy heifers on body condition score, body size, metabolic profile and future milk production. J Dairy Sci. 83(7):1468-1478

Anggraeni A, Fitriyani Y, Atabany A, Komala I. 2008. Penampilan produksi susu dan reproduksi sapi Friesian Holstein di Balai pengembangan perbibitan ternak sapi perah Cikole Lembang. Di dalam: [Nama tidak diketauhi], editor. Prosiding Nasional Teknologi Peternakan dan Veteriner [Internet]. [Waktu dan tempat peretemuan tidak diketahui]. Bogor (ID): Balitnak. hlm 1-9. [diunduh 2016 Juni 17]. Tersedia pada: http:// peternakan.litbang.Pertan ian.go.id/fullteks/semnas/ pro08-21.pdf

Atabany A. 2012. Efisiensi reproduksi dan produksi susu sapi Friesian Holstein pada generasi induk dan generasi keturunanya [disertasi]. Bogor (ID): Institut Pertanian Bogor

Blakely J, Bade DH. 1991. Ilmu Peternakan. Ed ke-4. Srigandono B, penerjemah. Jogyakarta (ID) : UGM Pr.

Ball PJ, Peters AR. 2007. Reproduction in Cattle. $3^{\text {th }}$ ed. Oxford. United Kingdom (US): Blackwell Publishing

Cozler YL, Peyraud JL, Troccon JL. 2008. Effect of feeding regime, growth intensity and age at first insemination on performances and longevity of Holstein heifers born during autumn. Livestock Sci. 124(2009):72-81.

Do CN, Wasana K, Cho. Y, Choi. T, Choi. B, Park. D, Lee. 2013. The effect of age at first calving and calving interval on productive life and lifetime profit in Korean Holsteins. Asian Australas J Anim Sci. 11(26):15111517.

[Dikjetnak] Direktorat Jenderal Peternakan. 2015. Laporan Tahunan Peternakan dan Kesehatan Hewan Kementerian Pertanian. Jakarta (ID): Kementerian Pertanian.

Foldager JK, Serjsen, Larsan JB. 1988. Feed intake and growth in the rearing period as well as the milk production in the first lactation in heifers feed ad libitum with barley, food sugar beets and long barley straw. J. Dairy Sci. 61: 173.

Hoffman PC. 1997. Optimum body size of holstein replacement heifers. J. Anim Sci 75 : 836-845.

Hardjosubroto W. 1994. Aplikasi Pemuliabiakan Ternak di Lapangan. Jakarta (ID): Gramedia Widiasarana Indonesia.

Heinrichs AJ, Weels SJ, Hurd HS, Hill GW, Dargatz DA. 1994. The national dairy heifer evaluation project: A profile of heifer management practices in the united states. J Dairy Sci. 77(6):1548-1555.

Murray BB. 2009. Maxemazing conception rate in dairy cows heat detection.[Internet] http:// www. omafra. gov.on.ca/ english/ livestock/dairy/faacts/84.048.html. [24 Novpember 2016].

Makin M. 1990. Studi sifat-sifat pertumbuhan reproduksi dan produksi susu sapi sahiwal cross (Sahiwal x Fries Holland) di Jawa Barat.[disertasi]. Bogor (ID): Institut Pertaian Bogor

Makin M. 2001. Perbandingan performan Sifat-Sifat Produksi susu dan reproduksi sapi perah sahiwal cross dengan fries holland. Journal Bionatura. 3(3): 173184.

Makin M, Suharwanto D. 2012. Performa sifat-sifat produksi susu dan reproduksi sapi perah Fries Holland di Jawa Barat. Journal Ilmu Peternakan.12 (2):1-6.

Moran J. 2012. Managing High Grade Dairy Cows in the Tropics. Australia (AU): Csiro Publishing

Norman HD, Raden PMV, Wright JR, Clay JS. 1999. Comparison of test interval and best prediction methods for estimation of lactation yield from monthly, a.m.-p.m and trimonthly testing. J. Dairy Sci. 82: 2438-2444.

Salisbury GW, Demarck NLV. 1961. Fisiologi Reproduksi dan Inseminasi Buatan pada Sapi. Djanuar R, penerjemah. Yogyakarta (ID): UGM press. Terjemahan dari: Physiology of Reproduction and Artificial Insemination of Cattle.

Steel RGD, Torrie JH. 1997. Prinsip dan Prosedur Statistika. Sumantri B, penerjemah. Jakarta (ID): PT. Gramedia Pustaka Utama. Terjemahan dari: Principles and Procedures of Statistics

Sarwiyono, Djoharjani T, Ibrahim MNM. 1993. Housing and management of dairy cattle in small scale farms of East Java, in Indonesia. Asian Ausralasian J Anim Sci. 6(3):389-394

Toelihere MR. 1985. Fisiologi Reproduksi pada Ternak. Bandung (ID): Angkasa Press.

Pennington JA. 2007. Dairy reproductive management using artificial insemination. University of Arkansas, United States Department of Agriculture and County Governments Cooperating. [Internet ]. http://www. uaex.edu. [24 Novpember 2016].

West JW, Mullinix BG, Sandifer TG. 1991. Effects of bovine somatotropin on physiologic responses of lactating holstein and Jersey cows during hot, humid weather. J Dairy Sci.74(3):840-851.

Yamada. 1992. Feeding and Managemnt of Dairy Cattle. Japan (JPN): Association of Livestock Technology Publishing. 